\title{
PENGARUH SUBSTITUSI SEBAGIAN RANSUM KOMERSIL DENGAN TEPUNG DAUN Indigofera sp TERHADAP LEMAK ABDOMEN AYAM BROILER
}

\author{
Bela Putra ${ }^{2}$, Mukhlis Dwi Putra ${ }^{1}$, Bopolion Pedi Utama \\ ${ }^{1}$ Fakultas Pertanian Universitas Muara Bungo \\ Email: belaputramsc@gmail.com
}

\begin{abstract}
ABSTRAK
Pakan substitusi sebagian ransum komersil dengan menggunakan indigofera sp adalah alternatif untuk memcahkan masalah mahalnya harga pakan broiler. indigofera $s p$ memiliki keunggulan kandungan protein yang tinggi serta mudah untuk didapatkan. Penelitian ini dilaksanakan dengan tujuan untuk mengetahui pengaruh substitusi sebagian ransum komersil dengan menggunakan tepung Indigifera sp terhadap lemak abdomen ayam broiler. Penelitian ini dilaksanakan dengan metode rancangan acak lengkap dengan 5 perlakuan dan 4 ulangan, dengan rincian; perlakuan I0 (100\% ransum komersil), I1 (92\% komersil + 16\% Indigofera sp, I3 (76\% ransum komersil $+24 \%$ Indigofera $s p)$, dan I4 (68\% ransum komersil $+32 \%$ Indigofera $s p)$. Hasil penelitian menunjukkan bahwa penggunaan Indigofera sp sebagai substitusi sebagian pakan komersil berbeda tidak nyata $(\mathrm{P}>0,05)$ terhadap semua parameter yang diteliti, yakni lemak abdomen, persentase lemak abdomen terhadap bobot hidup, persentase lemak abdomen terhadap karkas, persentase lemak abdomen terhadap organ dalam ayam broiler. Kesimpulan penelitian ini adalah penggunaan Indigofera sp hingga level 32\% tidak mempengaruhi lemak abdomen ayam broiler.
\end{abstract}

Kata Kunci : Indigofera sp, abdomen, broiler

\begin{abstract}
Feed substitution of most commercial rations using Indigofera $s p$ is an alternative to solve the problem of the high price of broiler feed. Indigofera $s p$ has high protein content and easily obtained. This research was conducted with the aim to study the substitution of most commercial rations using Indigifera $s p$ against broiler chicken belly fat. This research was conducted with a complete preparation method with 5 preparations and 4 replications, with details; I0 (100\% commercial rations), I1 (92\% commercial + 16\% Indigofera $s p)$, I3 (76\% commercial rations + $24 \%$ Indigofera $s p)$, and I4 (68\% commercial rations $+32 \%$ Indigofera $s p)$. The result show which using Indigofera $s p$ as the substitution of part commercial feed differed insignificantly $(\mathrm{P}>0.05)$ on all parameters discussed, namely belly fat, belly fat for live weight, belly fat for carcass, belly fat for organs in broiler chickens. The conclusion of this study is Indigofera sp use up to $32 \%$ level does not affect broiler chicken belly fat.
\end{abstract}

Keywords : Indigofera sp, belly fat, broiler

\section{Pendahuluan}

Ayam broiler merupakan jenis ayam hasil persilangan dari bangsa-bangsa ayam yang memiliki produktivitas tinggi, khususnya daging. Secara umum masyarakat Indonesia telah banyak mengembangkan usaha peternakan ayam broiler. Prospek usaha peternakan sangat besar baik untuk usaha skala makro maupun usaha skala mikro (Yemima, 2014).

Usaha peternakan ayam broiler terus mengalami perkembangan baik dari segi manajemen, feeding, dan breeding. Manajemen pemeliharaan ayam broiler sudah ditingkatkan baik aspek budidaya, manajemen pemberian pakan, manajemen 


\section{Jurnal Sains Peternakan}

Volume 8 No. 1, Juni 2020, pp:22-29

ISSN 2579-4450

perkandangan maupun manajemen pengendalian penyakit. Akan tetapi permasalahan yang dialami oleh pelaku peternakan ayam broiler adalah mahalnya harga pakan. Sebagai alternatif untuk mengurangi biaya pakan adalah dengan mensubstitusi sebagian pakan komersil dengan pakan alternatif yang mudah diperoleh serta memilki kandungan protein yang tinggi.

Pakan substitusi sebagian ransum komersil yang bisa digunakan adalah tanaman indigofera sp. Tanaman ini adalah jenis legume yang mengandung protein yang tinggi, mudah dikembangkan secara generatif, produksi hijauan tinggi, regrowing sangat cepat serta mampu beradaptasi dengan kekeringan (Abdullah, 2014). Penggunaan Indigofera $s p$ segar $10 \%$ masih baik pengaruhnya terhadap produksi telur, berat telur dan perbaikan warna yolk pada itik (Akbarillah et al. 2010). Indigofera sp juga bisa digunakan sebagai suplementasi pakan ayam broiler hingga level 15\% (Al-Rasyid dkk, 2019).

Hasil-hasil peneitian yang ditemukan jelas menunjukkan bahwa Indigofera $s p$ sangat potensial untuk dijadikan pakan suplementasi ayam broiler. Akan tetapi belum terlihat pengaruh substitusi sebagian ransum komersil dengan menggunakan tepung Indogofera sp terhadap lemak abdomen ayam broiler.

\section{Metode}

Penelitian menggunakan rancangan acak lengkap ( RAL ) dengan 5 perlakuan 4 ulangan, di mana setiap unit terdiri dari 5 ekor ayam. Adapun perlakuan sebagai berikut: I0: Kontrol (100\% ransum komersil )

I1: $92 \%$ ransum komersil $+8 \%$ Indigofera $s p$

I2:84\% ransum komersil $+16 \%$ Indigofera $s p$

$\mathrm{I} 3: 76 \%$ ransum komersil $+24 \%$ Indigofera $s p$

$\mathrm{I} 4: 68 \%$ ransum komersil $+32 \%$ Indigofera $s p$

Tabel 1.Kandungan Nutrisi Tepung Daun Indigofera $s p$

\begin{tabular}{lr}
\hline Kandungan & Tepung daun \\
\hline Protein kasar & $28,98 \% *$ \\
Serat kasar & $3,30 \% *$ \\
Lemak kasar & $8,49 \% *$ \\
Energi metabolic & $2800 \mathrm{kkl} / \mathrm{kg} * *$ \\
\hline Sumber : ${ }^{*}$ palupi (2014) &
\end{tabular}




\section{Jurnal Sains Peternakan}

Volume 8 No. 1, Juni 2020, pp:22-29

ISSN 2579-4450

Tabel 2. Nilai Gizi Ransum Penelitian Masing-Masing Perlakuan

\begin{tabular}{ccccc}
\hline \multirow{2}{*}{ Perlakuan } & \multicolumn{4}{c}{ Nilai gizi } \\
\cline { 2 - 5 } & $\mathrm{P}(\%)$ & $\mathrm{L}(\%)$ & $\mathrm{SK}(\%)$ & $\begin{array}{c}\mathrm{EM} \\
(\mathrm{Kkal} / \mathrm{kg})\end{array}$ \\
\hline I0 & 21,00 & 3,00 & 3,43 & 3050 \\
$\mathrm{I} 1$ & 21,63 & 3,02 & 3,87 & 3030 \\
$\mathrm{I} 2$ & 22,27 & 3,04 & 3,87 & 3010 \\
I3 & 22,92 & 3,07 & 4,31 & 2990 \\
$\mathrm{I} 4$ & 23,55 & 3,09 & 4,75 & 2970 \\
\hline
\end{tabular}

\section{Parameter Yang Diamati}

1. Bobot lemak abdomen mutlak

Lemak abdomen mutlak diperoleh dari lemak didalam rongga perut termasuk di sekitar organ pencernaan setelah ayam disembelih (Harisshinta, 2009).

2. Persentase bobot lemak abdomen berdasarkan bobot badan

Persentase lemak abdomen terhadap bobot badan dapat diperoleh dari penimbangan lemak yang terdapat pada rongga abdomen kemudian dibandingkan dengan bobot ayam kemudian dikalikan 100\% (Rizal, 2006). Dengan rumus dibawah ini:

\% Bobot lemak abdomen berdasarkan bb

$$
=\frac{\text { Bobot lemak abdomen }}{\text { bobot badan }} \times 100 \%
$$

3. Persentase bobot lemak abdomen berdasarkan bobot karkas dapat diperoleh dengan rumus berikut:

\% Bobot lemak abdomen berdasarkan karkas

$$
=\underline{\text { Bobot lemak abdomen }} \times 100 \%
$$
bobot karkas

4. Persentase bobot lemak abdomen berdasarkan bobot organ dalam

Persentase bobot lemak abdomen berdasarkan organ dalam dapat diperoleh dengan rumus berikut:

$\%$ Bobot lemak abdomen berdasarkan bobot organ dalam

$=$ Bobot lemak abdomen $\times 100 \%$ organ dalam

\section{Hasil dan Pembahasan}

\section{Bobot lemak abdomen mutlak}

Pengamatan bobot lemak mutlak ayam broiler dengan penggantian sebagian ransum komersil dengan tepung daun Indigofera $s p$ selama penelitian tertera pada Tabel 3. 


\section{Jurnal Sains Peternakan}

Volume 8 No. 1, Juni 2020, pp:22-29

ISSN 2579-4450

Tabel 3. Rataan berat lemak mutlak ayam broiler pada masing-masing perlakuan selama penelitian (gram/ekor)

\begin{tabular}{lc}
\hline Perlakuan & Rataan \\
\hline I0 & 0,2875 \\
I1 & 0,3625 \\
I2 & 0,4125 \\
I3 & 0,3000 \\
I4 & 0,3250 \\
\hline
\end{tabular}

Berdasarkan hasil sidik ragam memperlihatkan bahwa perlakuan berpengaruh tidak nyata terhadap bobot lemak ayam broiler. Hal ini diduga disebabkan jumlah kandungan nutrisi semua perlakuan relatif sama. Salah satu yang mempengaruhi pembentukan lemak abdomen adalah pakan yang dikonsumsi (Tumuva and Teimouri 2010). Selain faktor pakan, pembentukan lemak abdomen juga dipengaruhi oleh umur. Penelitian ini menggunkan ayam yang sama umurnya sehingga menyebabkan tidak berbedanya kandungan lemak abdomen pada setiap perlakuan. Sejalan dengan pernyataan (Novele et al., 2008) yang menyatakan bahwa pengaruh umur sangat menentukan jumlah kadar lemak abdomen ayam broiler.

Pembentukan lemak abdomen terjadi dengan adanya kelebihan energi yang dikonsumsi. Secara umum energi dihasilkan dari perombakan karbohidrat. Pada penelitian ini menggunakan ransum dengan toal energi relatif tidak berbeda nyata mengakibatkan pembentukan lemak abdomen pada semua perlakuan juga sama.

Kandungan lemak abdomen hasil penelitian ini relatif rendah diduga efesiennya pemanfaatan energi yang dihasilkan dari pakan untuk proses metabolisme dalam tubuh. Akhardiarto (2010) menyatakan bahwa terjadinya penimbunan lemak pada organ dalam tubuh disebabkan adanya kelebihan energi dalam proses metabolisme normal. Sejalan dengan pendapat Yusmaini (2008) yang menyatakan bahwa kelebihan energi akan dikonversi kedalam lemak dan disimpan di dalam tubuh.

Faktor lain yang mempengaruhi pembentukan lemak di dalam rongga tubuh adalah kandungan SK dari pakan yang dikonsumsi. Pada penelitian ini kandungan SK dari setiap perlakuan relatif sama sehingga mengakibatkan kandungan lemak abdomen juga sama. Sesuai dengan pendapat Akhardiarto (2010) yang mengemukakan bahwa peranan SK dalam pembentukan lemak adalah mengikat asam empedu di dalam saluran pencernaan sehingga mengakibatkan terhambatnya penyerapan lemak, serta akan mengeluarkannya melalui feses. 


\section{Jurnal Sains Peternakan}

Volume 8 No. 1, Juni 2020, pp:22-29

ISSN 2579-4450

\section{Persentase Bobot Lemak Abdomen Berdasarkan Bobot Badan}

Persentase lemak abdomen diperoleh dengan membandingkan bobot lemak abdomen dengan bobot hidup dikalikan 100\%. Pengamatan persentase bobot lemak berdasarkan bobot badan ayam broiler dengan penggantian sebagian ransum komersil dengan tepung daun Indigofera sp selama penelitian pada Tabel 4.

Tabel 4. Rataan berat lemak berdasarkan bobot hidup ayam broiler pada masing-masing perlakuan selama penelitian (\%)

\begin{tabular}{ll}
\hline Perlakuan & Rataan \\
\hline I0 & 0.0170 \\
I1 & 0.0242 \\
I2 & 0.0227 \\
I3 & 0.0179 \\
I4 & 0.0202 \\
\hline
\end{tabular}

Hasil sidik ragam menunjukkan bahwa perlakuan berpengaruh tidak nyata terhadap persentase berat lemak abdomen berdasarkan bobot hidup. Tingkat konsumsi pakan pada penelitian ini relatif sama sehingga menyebabkan bobot hidup tidak berbeda nyata.

Hal ini sesuai dengan pendapat Deaton dan Lott (1985) bahwa konsumsi ransum akan mempengaruhi bobot hidup. Semakin tinggi konsumsi ransum serta diikuti dengan daya cerna yang baik maka akan semakin tinggi serapan nutrisi di dalam tubuh. Serapan nutrisi ini akan digunakan untuk pembentukan daging melalui proses metabolisme. Hal ini tentunya akan sangat berdampak dengan bobot hidup.

Pemberian tepung daun Indigofera $s p$ sampai dengan 32\% dalam ransum ayam broiler memiliki potensi yang sama dengan ransum komersil untuk meningkatkan bobot potong. Hal ini berarti bahwa protein tepung daun Indigofera $s p$ dapat menggantikan peranan protein hewani pada ransum komersil dalam peningkatan bobot hidup.

\section{Persentase Berat Lemak Abdomen Berdasarkan Bobot Karkas}

Pengamatan berat lemak berdasarkan bobot karkas ayam broiler dengan penggantian sebagian ransum komersil dengan tepung daun Indigofera sp selama penelitian pada Tabel 5 .

Tabel 5. Rataan berat lemak berdasarkan karkas ayam broiler pada masing- masing perlakuan selama penelitian (\%)

\begin{tabular}{ll}
\hline Perlakuan & Rataan \\
\hline I0 & 0.0256 \\
I1 & 0.0328 \\
I2 & 0.0328 \\
I3 & 0.0219 \\
I4 & 0.0278 \\
\hline
\end{tabular}




\section{Jurnal Sains Peternakan}

Volume 8 No. 1, Juni 2020, pp:22-29

ISSN 2579-4450

Dari tabel diatas memperlihatkan persentase bobot lemak berdasarkan bobot karkas yang paling tinggi terdapat pada perlakuan I1 dan I2 yaitu $0.0328 \%$. Hasil sidik ragam menunjukkan bahwa perlakuan tidak berpengaruh nyata terhadap persentase bobot lemak berdasarkan karkas ayam broiler $(\mathrm{P}>0.05)$. Hasil penelitian ini lebih rendah dibandingkan dengan hasil penelitian Lingga dkk (2016) yaitu berkisar antara 1,96-2,30\% dari bobot karkas.

Menurut Bidura dkk, (2007), Karkas broiler adalah bagian tubuh ayam yang disembelih lalu dikeluarkan isi perut, kaki, leher, kepala, bulu, dan darah. Sedangkan Lemak Abdominal adalah Lemak abdominal adalah lapisan lemak yang terdapat disekitar gizzard dan lapisan antara otot abdominal dan usus (Salam dkk., 2013)

\section{Berat Lemak Berdasarkan Organ Dalam}

Pengamatan berat lemak berdasarkan bobot organ dalam ayam broiler dengan penggantian sebagian ransum komersil dengan tepung daun Indigofera $s p$ selama penelitian pada Tabel 6 .

Tabel 6. Rataan berat lemak berdasarkan organ dalam ayam broiler pada masingmasing perlakuan selama penelitian (\%)

\begin{tabular}{ll}
\hline Perlakuan & Rataan \\
\hline I0 & 3.7562 \\
I1 & 5.7951 \\
I2 & 4.6822 \\
I3 & 3.9734 \\
I4 & 3.8944 \\
\hline
\end{tabular}

Dari tabel diatas memperlihatkan persentase bobot lemak berdasarkan organ dalam yang paling tinggi terdapat pada perlakuan I1 yaitu $5.7951 \%$ dan yang paling rendah terdapat pada perlakuan I0 yaitu $3.7951 \%$. Hasil sidik ragam menunjukkan bahwa perlakuan tidak berpengaruh nyata terhadap persentase bobot lemak berdasarkan organ dalam ayam broiler ayam broiler $(\mathrm{P}>0.05)$.

Pergantian sebagian ransum komersil dengan tepung daun indigofera sp hingga level 32\% tidak berpengaruh terhadap organ dalam broiler. Tepung daun Indigofera $s p$ tidak menghambat kinerja organ dalam sehingga mengakibatkan ukuran organ dalam tetap normal. Kadar SK dalam semua perlakuan relatif sama sehingga tidak menghambat proses kinerja organ dalam broiler. Sesuai dengan pernyataan (Santi , 2018) bahwa semakin tinggi SK dalam yang dikonsumsi maka akan berakibat dengan terhambatnya kinerja organ dalam baik dalam proses pencernaan maupun penyerapan. 


\section{Jurnal Sains Peternakan}

Volume 8 No. 1, Juni 2020, pp:22-29

ISSN 2579-4450

Kinerja organ dalam juga sangat ditentukan oleh kadar zat toksik dalam pakan. Terbukti bahwa Indigofera $s p$ tidak mengandung zat racun yang dapat menghambat kinerja organ dalam broiler sehingga ukurannya relatif sama dari setiap perlakuan.

\section{Kesimpulan}

Penggantian sebagian ransum komersil dengan tepung daun Indigofera $s p$ dalam pakan ayam broiler sampai level $32 \%$ tidak berpengaruh nyata terhadap bobot lemak abdomen ayam broiler, persentase bobot lemak berdasarkan bobot badan, persentase bobot lemak berdasarkan bobot karkas, persentase lemak berdasarkan bobot organ dalam.

\section{Daftar Pustaka}

Abdullah, L. 2014. Prospektif agronomi dan ekofisiologi indigofera zollingeriana sebagai tanaman penghasil hijauan pakan berkualitas tinggi. Pastura, 3(2).

Akbarillah TD, Kususiyah, Hidayat. 2010. Pengaruh penggunaan daun indigofera segar sebagai suplemen pakan terhadap produksi dan warna yolk itik. J Sain Peternakan Indonesia. 5:27-33.

Akhadiarto, S. 2010. Pengaruh pemberian probiotik temban, biovet dan biolacta terhadap persentase karkas, bobot lemak abdomen dan organ dalam ayam broiler. Jurnal sains dan teknologi Indonesia, 12(1).

Al-Rasyid, M. Y. A., \& Saade, A. 2019. Pengaruh Tepung Daun Indigofera Dalam Ransum Terhadap Kualitas Karkas Broiler. Jurnal Agrisistem, 15(1), 29-34.

Bidura, I. G., Candrawati, D. P. M. A., \& Sumardani, N. L. G. 2000. Pengaruh Penggunaan Daun Katuk (Saurupus Androgynus) dan Daun Bawang Putih (Allium Sativum) dalam Ransum terhadap Penampilan Ayam Broiler1. Majalah Ilmiah Peternakan, 10(1).

Deaton, J. W. and B. D. Lott. 1985. Age and dietary energy effect on broiler abdominal fat deposition. Poult Sci. 64: 2161-2164

Harisshinta, R. 2009. Pengaruh Penggunaan Limbah Teh dalam Pakan Terhadap Persentase Karkas, Lemak Abdominal, Kandungan Lemak Daging dan Berat Organ Dalam Ayam Pedaging. Fakultas Peternakan Universitas Brawijaya, Malang. (Skripsi Sarjana Peternakan)

Lingga, F. T., Sulasmi., T. Armansyah, S. Aisyah., Ismail., B. Panjaitan dan Razali. 2016. Pengaruh pemberian ekstrak daun bandotan (Ageratum conyzoides) terhadap berat karkas dan lemak abdominal ayam broiler. Jurnal Media Veterinaria. Vol. 10 No. 1

Novele, D. J., Ng'Ambi, J. W., Norris, D., \& Mbajiorgu, C. A. 2008. Effect of sex, level and period of feed restriction during the starter stage on productivity and carcass characteristics of Ross 308 broiler chickens in South Africa. International Journal of Poultry Science, 7(6), 530-537. 


\section{Jurnal Sains Peternakan}

Volume 8 No. 1, Juni 2020, pp:22-29

ISSN 2579-4450

Palupi, NS. 2014. Evaluasi Komponen Bioaktif Tanaman UntukKesehatan. Southeast Asian Food and Agricultural Science and Technology (SEAFAST) Center Research and Community Service Institution. Bogor Agricultural University.

Rizal, Y. 2006. Ilmu Nutrisi Unggas. Padang : Andalas University Press

Salam, S., A. Fatahilah., D Sunarti dan Isroli. 2013. Bobot karkas dan lemak abdominal broiler yang diberi tepun jintan hitam (Nigella sativa) dalam ransum selama musim panas. Jurnal Sains Peternakan, 11 (2): 84-89

Santi, M. A. (2018). Penggunaan tepung pucuk indigofera zollingeriana sebagai pengganti bungkil kedelai dalam ransum dan pengaruhnya terhadap kesehatan ayam broiler. Jurnal Peternakan (Jurnal of Animal Science), 1(2), $17-22$.

Sirait, J., Simanihuruk K, Hutasoit R. 2009. The potency of Indigofera sp. as goat feed: production, nutritive value and palatability. In: Proceeding of International Seminar on Forage Based Feed Resources. Bandung, 3-7 Agustus 2009. p. 47

Tumuva, E., \& Teimouri, A. 2010. Fat deposition in the broiler chicken: a review. Journal Scientia Agriculturae Bohemica, 41, 121-128.

Yanti, M. A. 2019. Pengaruh Substitusi Protein Tepung Pucuk Indogofera Zollingeriana Dengan Protein Bungkil Kedelai Dalam Ransum Terhadap Organ Dalam Broiler. Jurnal Peternakan (Jurnal of Animal Science), 2(2), 15-20.

Yemima. 2014. Analisis Usaha Peternakan Ayam Broiler Pada Peternakan Rakyat di Desa Karya Bakti, Kecamatan Rungan, Kabupaten Gunung Mas, Provinsi Kalimantan Tengah. Jurnal Ilmu Hewani Tropika Vol.3 No.1; 28-32

Yusmaini. 2008. Pengaruh Suhu Panas dan Umur Pemotongan terhadap Bobot Relatif, Lemak Abdominal Kandungan Lemak Daging Paha dan Kolesterol Total Plasma Darah Ayam Broiler. Tesis. Fakultas Peternakan Universitas Andalas. Padang. 